DOI: $10.31249 / \mathrm{rsm} / 2021.02 .13$

\title{
М.В. Бекленищева
}

\section{ЗАРУБЕЖНЫЕ ПОЕЗАКИ СВЕРАПОВЧАН В 1950-1980-е ГОАЫ КАК ФАКТОР ИЗМЕНЕНИЯ ВОСПРИЯТИЯ МИРА}

Аннотация. Статья посвящена анализу влияния поездок за границу на мировосприятие. В статье представлена историография поездок в нетуристских целях, т.е. не в отпуск, охарактеризована источниковая база. На основе значительного массива различных видов документов очерчена география выездов за рубеж, предложена систематизачия по иелям поездок (рабочие командировки, научные стажировки, студенческие выезды) и по их продолжительности. Изучены этапы поездки от подготовки до возвращения домой. Рассмотрены организационные моменты подготовки к выезду и бытовые условия пребывания за рубежом. Большое внимание уделено разнообразию вариантов организации питания, проживания, проведения досуга в поездках. Выявлено, что существенным отличием продолжительных и краткосрочных поездок являлось их финансовое обеспечение. Отмечено, что продолжительная поездка за рубеж являлась, в том числе, возможностью улучшения материального благосостояния командируемых.

В ходе исследования сделан вывод о том, что на изменение - и даже трансформациюю - восприятия мира влияло множество факторов, включая страну пребывания, продолжстельность поездки, возраст отправлявшегося за рубеж, бытовые условия, а также сумма денег, которой располагал направлявшийся за гранииу. Само пребывание за рубежом могло вызывать как положительные, так и отрицательные эмоции. В поездке и по ее завершении в большей или меньшей степени могло изменяться восприятие себя, своей страны, страны пребывания, третьих стран как на позитивное, так и на негативное. Это обстоятельство необходимо учитывать при изучении исторических процессов второй половины ХХ в.

Ключевые слова: выезд за рубеж; загранкомандировка; стажсировка; интеротряд.

Бекленищева Мария Владимировна - аспирант,

Уральский федеральный университет

имени первого Президента России Б.Н. Ельцина.

Россия, Екатеринбург.

E-mail: bekmv88@yandex.ru 


\title{
Beklenishcheva M.V. Foreign trips of Sverdlovsk residents in the $1950 \mathrm{~s}$ and 1980s as a factor in changing (transforming) the perception of the world
}

\begin{abstract}
This article analyzes the impact of trips abroad not on vacation on the perception of the world. The article presents the historiography of trips for non-tourist purposes and describes the source base. Based on a significant number of different documents, the geography of trips abroad is presented, and systematization is proposed for trips (business trips, research internships, and student trips) and their duration. The stages of the trip from preparation to completion were studied. Also organizational aspects of preparation for departure and living conditions abroad are considered. Attention is focused on the variety of options for catering, accommodation, and leisure activities on trips. It was revealed that a significant difference between long and short-term trips was their financial security. It was noted that a long trip abroad is, among other things, an opportunity to improve the material well-being of those who leave. Many people brought goods that were scarce in the Soviet Union.

The study showed that many factors influenced the change and even transformation of the perception of the world, including the country of departure, the duration of the trip, the age of the person traveling abroad, living conditions, as well as the amount of money that can be spent. Staying abroad during a business trip could cause positive and negative emotions. During the trip and at the end of it, the perception of yourself, your country, the host country, and third countries could change both positively and negatively. This should be taken into account when studying the historical processes of the second half of the XX century.
\end{abstract}

Keywords: travel abroad; traineeship; international team; a mission.

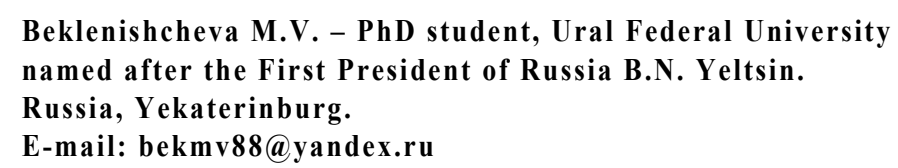

Во второй половине XX в. активная внешняя политика Советского государства в условиях меняющейся политической карты мира приводит к существенному расширению международных контактов. Одной из наиболее интересных проблем истории международного сотрудничества Советского Союза является выезд советских граждан за рубеж: цели поездок, идеологические и экономические задачи СССР, а также влияние, по-прежнему доступной далеко не каждому, заграницы на сознание советских людей.

В этой статье мы попытаемся проанализировать влияние поездок на восприятие мира советскими гражданами на примере жителей Свердловской области в зависимости от цели поездки, продолжительности, страны пребывания, а также возраста выезжавших. Для этого определим круг источников о зарубежных поездках, а также классифицируем нетуристские поездки советских граждан за рубеж. 
Как справедливо отмечают многие французские исследователи [Dullin 2011, p. 35; Dufraisse 2016, p. 35; Ermolaeva 2015], жители СССР начинали выезжать за границу еще до смерти Сталина, но все-таки большинство ученых связывает начало массовых выездов с хрущевской оттепелью. В ряде работ, посвященных изучению культурной дипломатии СССР, подчеркивается, что загранпоездки жителей СССР были демонстрацией открытости Западу, а делегаты олицетворяли успехи строя, при этом особое внимание уделялось таким мельчайшим деталям как, например, опрятный внешний вид и проч. [Dufraisse, Momzikoff, Pedemonte 2016, p. 16; Le Poittevin 1998, p.; Coeuré 2016, p. 122]. Зарубежные исследователи сходятся во мнении, что влияние было обоюдным.

В российской историографии в конце 2000-2010-х годах также растет интерес к изучению выездного туризма. Вместе с тем значительный процент выездов за границу составляли нетуристические поездки. Этой темы касается А.С. Иванова в контексте изучения вопросов функционирования магазинов «Берёзка» [Иванова 2017]. В ряде работ поднимается проблема зарубежных контактов советских ученых технических и естественных специальностей, часть из них приурочена к юбилейным датам советских и российских ученых [Шабалина 2012, с. 101; Виталию Яковлевичу 2008, с. 6; Самокиш 2019, с. 46; Нагорных 2019, с. 255]. Отдельный блок исследований посвящен выездам за границу в годы холодной войны по религиозной линии [подробнее см.: Пивоваров 2017, с. 185-215]. Рассматриваются вопросы выезда за рубеж советских деятелей культуры, к примеру статья С. Гонсальвеса посвящена гастролям советских танцоров за границей в 1954-1968 гг. Автор делает акцент на том, как налаживался диалог между разными танцевальными школами, происходил обмен опытом. Советские танцоры могли приобрести за границей концертную одежду, считавшуюся наиболее качественной [Gonçalves 2016, p. 80]. Изучению пребывания советских спортивных делегаций за рубежом в 1952-1960-х годов посвящена работа С. Дюфреса [Dufraisse, 2016, p. 35-45]. Темы выезда советских спортсменов за границу касается О’Махоуни в своей работе о советском спорте и его визуализации в искусстве, изданной сначала на английском языке [O'Mahony 2006], а затем переведенной на русский [О’Махоуни 2010].

В целом же тема нетуристских поездок, как отдельного направления исследований, еще не получила достаточного освещения в научной литературе.

Источниковую базу исследования можно условно разделить на три группы. Первую группу источников составляют документы, отложившиеся в государственных (в том числе бывших партийных), муниципальных и ведомственных архивах и музеях. Это решения о направлении в поездку, составы делегаций, отчеты о командировках, фотодокументы, материалы (чертежи и 


\section{ФЕНОМЕНОЛОГИЯ СОВЕТСКОГО ОБЩЕСТВА}

проч.). Анализ данной группы источников позволяет охарактеризовать цели и результаты поездок.

Вторая группа источников - это сообщения в периодической печати того времени о поездке. Визиты за рубеж широко освещались в региональной и местной периодике и изучение данной группы источников позволяет сориентироваться в географии поездок.

Третья группа - это мемуары, воспоминания, записки участников событий, опубликованные либо сразу после окончания поездки, либо по прошествии многих лет, либо неопубликованные. Неопубликованные воспоминания отложились в личных фондах музеев предприятий, специалисты которых направлялись за рубеж. Кроме того, уникальный материал может быть выявлен благодаря методу устной истории. Именно третья группа источников составляет базу для изучения степени влияния зарубежных поездок на изменение (трансформацию) восприятия мира. Вместе с тем в целях получения объективного исторического знания вопрос не может рассматриваться без учета двух других групп источников.

Рассмотрим различные варианты нетуристских поездок на примерах жителей Свердловской области. Автором были проведены опросы в формате интервьюирования и анкетирования. В опросах приняли участие 19 человек 14 мужчин и пять женщин, посетившие Чехословакию (четыре человека), ФРГ (два человека), Вьетнам (три человека), ГДР (шесть человек), Афганистан (два человека), Венгрию (один человек), Монголию (один человек), Кубу (один человек), Бельгию (один человек). В структуре опроса выделено восемь разделов. Респондентам предлагалось заполнить данные, включающие вопросы о лице, совершившем поездку; информацию о направлении, целях, периоде, организаторах поездки; рассказать об этапах подготовки к поездке; организационных моментах пребывания за рубежом; часть вопросов касалась общения с иностранцами во время поездки; финансово-экономических аспектах поездки; последствиях поездки; в заключительном разделе предлагалось сообщить дополнительную информацию о поездке, которая важна, по мнению респондентов.

По результатам проведенных комплексных исследований, предлагается классификация поездок по времени пребывания за границей - продолжительные более одного месяца и краткосрочные до одного месяца. Существенным отличием краткосрочных и долговременных командировок являлся размер оплаты труда (стипендии) направлявшихся за границу.

Наибольшую по численности группу выезжавших за рубеж в продолжительные нетуристские поездки составляли те, кто направлялся за границу по работе, зачастую с супругами и детьми. Так как Свердловская область являлась промышленным регионом, значительная часть командированных за рубеж составляли инженеры и рабочие предприятий, участвовавшие в строи- 
тельстве или наладке индустриальных объектов в Азии, Африке, Европе и Латинской Америке. Такие поездки длились в среднем от шести месяцев до двух лет [Вечер дружбы; Материалы о Костомарове; Крепкие руки; Яковлев; Почти год; Бычков; Галактионов 1963; Друзья обмениваются; От чешских друзей; Альбом друзей]. Сотрудники промышленных предприятий выезжали на стажировки за рубеж, в том числе в ГДР и Японию [Акифьева 2015, с. 113; В Болгарию, Японию, Швецию].

Другая часть выезжавших - это представители силовых структур и призывники, проходившие срочную службу в рядах советской армии. В ходе проведенного анкетирования автором выявлено, что свердловчане служили в ГДР, Чехословакии и Венгрии [Результаты опроса], а продолжительность поездок могла составлять более пяти лет. Важно отметить, что по линии Министерства обороны за рубеж направлялись не только мужчины. К примеру, в 1988-1989 гг. в военной части в Чехословакии бухгалтером работала женщина 21 года [Результаты опроса]. Свердловчане трудились за рубежом на дипломатическом поприще. Например, Я.П. Рябов, возглавлявший Свердловский обком КПСС в 1970-е годы, был послом СССР во Франции в 1986-1990 гг. За границу направлялись специалисты в области авиастроения. В качестве примера приведем свердловских авиатехников, трудившихся во Вьетнаме. Свердловчане выезжали в командировки в зоны военных действий, например - в Афганистан, с гуманитарными миссиями. Преподаватели среднеспециальных и высших учебных заведений работали в течение нескольких лет на Кубе и в Чехословакии.

К категории продолжительных отнесем зарубежные поездки студентов, аспирантов и докторантов для стажировок и прохождения практики. Развивались научные контакты между СССР и Францией. В 1963 г. в Париж на стажировку в составе группы молодых советских ученых-физиков был направлен аспирант Уральского политехнического института (УПИ) Л.Н. Новиков, вспоминавший, что «получали стипендию в нашем посольстве и жили в студенческом общежитии в знаменитом Латинском квартале» [Новиков]. В 1976-1977 гг. в ФРГ на десятимесячную стажировку для подготовки докторской диссертации выезжал доцент философского факультета Уральского государственного университета А.В. Гайда, который позже был направлен в продолжительную командировку в Прагу для преподавания в Карловом университете [Гайда 2007, с. 16]. На языковую годичную стажировку и одновременно для работы в качестве переводчика на строительстве промышленного предприятия выезжал на Кубу свердловчанин - студент четвертого курса РУДН. На базе УПИ функционировал интернациональный студенческий стройотряд. Студенты интернационального стройотряда направлялись в Афганистан (фото 1) и в город Пльзень в Чехословакии (фото $2,3,4)$ в рамках побратимских связей Свердловской и Западночешской областей. Во время 
нахождения студентов УПИ в Пльзене в Свердловске работали ребята из чехословацкого стройотряда.

В краткосрочные зарубежные поездки продолжительностью менее одного месяца направлялись советские граждане в составе партийных, правительственных, муниципальных, комсомольских делегаций, «поездов дружбы», спортсмены, ученые, принимавшие участие в международных конференциях, симпозиумах, артисты и другие деятели искусств. Вспомним, к примеру, работы режиссера, сценариста и оператора И.К. Персидского «Республика Чад» (1968) [Республика Чад] и Республика Сейшельские Острова (1981) [Персидский. Сейшельские острова 1981], а также «Вьетнамские Встречи» (1976) о поездке Народного ансамбля танца профтехобразования Дворца молодежи г. Свердловска для выступления на мероприятиях, посвященных победе Вьетнамской революции в декабре 1975 г. [Персидский 1976], «Мы - побратимы» (1981), снимавшийся на территории Свердловской и Западночешской областей [Персидский. Мы - побратимы 1981]. Также не стоит забывать и о представителях туриндустрии: для организации поездок советских туристов за границу в служебные командировки направлялись сотрудники Интуриста и Спутника.

Очевидно, что любые поездки, а уж тем более за рубеж, способствуют изменениям в мировосприятии. Это погружение в иную, часто непривычную, среду, значительные объемы новой информации, знакомство с людьми, наконец, изменение режима дня, структуры питания и проч. Именно поэтому можно утверждать, что выезды за границу в нетуристских целях способствовали изменению, а возможно, и трансформации восприятия мира. Степень этого влияния зависела от множества факторов - возраст выезжающих, уровень образования, цель поездки, страна и продолжительность пребывания.

Вопрос о возможности поездки поднимался задолго до того, как человек отправлялся за рубеж. На этапе подготовки с кандидатами проводились собеседования в различных инстанциях, начиная от инструктажа в районном комитете партии и заканчивая собраниями в Министерстве иностранных дел в Москве. Как вспоминает авиатехник - участник двухгодичной командировки во Вьетнам в 1982-1984 гг., вызывало удивление, что люди, проводившие собеседования и принимавшие решение о рекомендации того или иного специалиста для работы за рубежом, никогда не проверяли профессиональные знания и навыки, необходимые для выполнения работы. Все вопросы «экзаменаторов» лежали в идеологической плоскости [Интервью 1]. Вместе с тем участники анкетирования на вопрос о том, почему, по их мнению, за границу направили именно их, отмечают свою хорошую профессиональную подготовку. Респонденты, направленные за рубеж в качестве переводчиков, отмечали свои личные качества и высокий уровень владения иностранными языками [Результаты опроса]. Для поездки в составе интернационального 
студенческого стройотряда в Пльзень во время летних каникул претенденты в течение предшествующего учебного года занимались комсомольской или общественной работой, одним из условий поездки являлись успешно сданные сессии. К примеру, в 1988 / 89 уч. г. силами студентов был сделан ремонт общежитий для приема чехословацкого студенческого стройотряда в рамках международного обмена. Кроме того, существовал безвалютный обмен: уезжая, свердловские студенты должны были оставить своим чехословацким «коллегам» каждому по 100 руб., а чехословацкие студенты оставляли эквивалент - по 1000 крон. Эти деньги нужно было заработать. Поэтому в течение учебного года бригады студентов разгружали вагоны на овощебазе, чистили морозильники на мясокомбинате и т.п. Один из участников такой поездки сообщил, что их бригада заработала более 700 руб., т.е. более 70 руб. на человека, что являлось хорошим показателем, а оставшиеся 30 руб. добавлялись из стипендии [Интервью 3].

Как вспоминает мужчина, направленный в ФРГ на научную стажировку в 1976-1977 гг., супруга и ребенок не могли поехать вместе с ним [Интервью 4]. Если речь шла о членах семьи выезжавших за рубеж в социалистические страны, процедура оформления документов включала только оформление заграничного паспорта, а если речь шла о детях, то только фотографирование на загранпаспорт [Результаты опроса]. Как правило, выезжавшие за рубеж свердловчане прибывали к месту назначения на самолете. Аэропорт Свердловска в то время обслуживал внутренние рейсы, в связи с чем необходимо было лететь с пересадками. Однако в ряде случаев для делегаций, путешествующих по линии побратимских связей, организовывались прямые беспересадочные рейсы из Свердловска в Прагу и обратно, а в аэропорту работал временный контрольно-пропускной пункт и пограничный контроль проходили непосредственно в Свердловске.

Проживание за рубежом было организовано в квартирах, гостиницах квартирного типа, общежитиях, а в случае с солдатами срочной службы - в казармах. Бытовым условиям проживания респонденты дают подчас диаметрально противоположные оценки. Жившие в квартирах в ГДР и Чехословакии считают, что условия были хорошие, студент-переводчик назвал жилищные условия на Кубе «спартанские, как для молодого специалиста», семья, жившая во Вьетнаме, поделилась воспоминаниями о тараканах размером с ладонь и крысах величиной с половину руки в гостинице квартирного типа. Мужчина-инженер, работавший в 1979 г. в течение двух месяцев на УланБаторской ТЭЦ, проживал какое-то время с коллегами из СССР в небольшой трехкомнатной квартире, позже он переехал в гостиницу. Он особо отметил скромный уровень жизни в МНР. Так, некоторые сотрудники ТЭЦ жили в юртах в связи с высокой стоимостью коммунальных услуг, а жившие в хру- 
щевках отапливали жилье печками-буржуйками, что «было видно по торчащим из окон трубам» [Результаты опроса].

Все респонденты отмечают, что в ходе поездок удалось попутешествовать по стране пребывания, посетить по несколько городов. Вместе с тем свобода перемещений, особенно сопровождавших лиц (т.е. жен и детей), была ограниченной. В ГДР свободное перемещение возможно было по территории войсковой части СССР, а, к примеру, во Вьетнаме женам авиатехников не разрешалось покидать гостиницу без сопровождающих. Отношение местного населения к свердловчанам в целом характеризуется как доброжелательное. Мужчина, совершивший поездку в Бельгию в 1988 г. в качестве сопровождающего участников Симпозиума молодых экологов, оценил отношение как сдержанное («относились к нам с осторожностью») [Результаты опроса].

При продолжительном пребывании были возможны несколько схем оплаты труда. Один из вариантов - это дробление заработной платы на две-три части. К примеру, авиатехнику, работавшему во Вьетнаме, по месту основной работы в Советском Союзе начислялось $60 \%$ от средней заработной платы. Часть зарплаты выплачивалась в чеках Внешпосылторга. Эти средства можно было израсходовать по возвращении в Советский Союз на приобретение товаров в магазинах «Березка». Третья часть выплачивалась в местной валюте и тратилась на продукты питания, одежду, обувь и другие бытовые нужды в магазинах Торгпредства. Другая схема оплаты - это получение ежемесячно всей заработанной суммы в долларах без деления на части [Интервью 1].

Финансовое обеспечение продолжительной поездки представлялось как достаточное, а командировка за рубеж была возможностью улучшить материальное благосостояние. Часть жителей Страны Советов предпочитала не расходовать деньги за рубежом. В 1980-е годы, несмотря на массовое жилищное строительство в предшествующий период, по-прежнему оставался актуальным жилищный вопрос. Поездка на работу за границу становилась возможностью для молодых семей с детьми обзавестись собственным кооперативным жильем и предметами интерьера. Другая часть советского населения привозила из-за границы, буквально, все для себя и своих близких: ковры, пледы, обувь и одежду, шубы, джинсы, посуду, в том числе сервизы, сыры, сладости, бытовую технику, книги. Выбор определялся качеством, ценой товаров, а также их дефицитом или отсутствием в Советском Союзе.

Любопытно наблюдение мужчины, работавшего на ТЭЦ в Монголии, об отношении местного населения к совершению покупок иностранцами. Неподалеку от ТЭЦ был расположен кожевенный комбинат. Выяснилось, что работавшие в МНР чехословацкие специалисты могли заказать пошив одежды независимо от продолжительности нахождения в стране, а советские специалисты - только после пребывания более трех месяцев в Монголии. Изделия, 206 
заказанные и не выкупленные, в свободную продажу не поступали. Тем не менее командированному удалось купить для дочери шубу, от которой отказалась чешская семейная пара [Результаты опроса].

Студенты интернациональных студенческих стройотрядов, с учетом разрешенной к вывозу денежной суммы, безвалютного обмена, а также заработанного в Чехословакии, располагали суммой примерно в 350 руб., которую также тратили на одежду, в первую очередь на приобретение джинсов, которые стоили 28-30 руб., кроссовок (22 руб.), а также пиво в банках. Если джинсы и кроссовки в Свердловске можно было приобрести на «черном рынке», то баночное пиво было диковинкой. По воспоминаниям мужчины, который был участником стройотряда в 1989 г., привезенные из Чехословакии шесть банок пива он решил взять с собой в Сочи, куда отправился к друзьям на каникулы после возвращения в Свердловск. При досмотре в аэропорту молодой человек был остановлен, так как сотрудники, отвечавшие за безопасность, никогда не видели баночного пива, и одну из банок даже пришлось открыть, чтобы продемонстрировать ее содержимое.

Некоторые жители Свердловской области, направлявшиеся в краткосрочные заграничные командировки, также отметили, что покупали дефицитные товары. Однако в большинстве случаев ограниченный бюджет (обменивалось только 30 руб.) позволял приобрести только сувениры. При этом некоторые выезжавшие отмечали, что чувствовали себя в другой стране крайне неуютно в связи с невозможностью купить понравившиеся вещи. А, к примеру, участник поездки идеологических работников в Западночешскую область Чехословакии в 1969 г. отметил, что деньги было некуда тратить, так как все расходы по проживанию, питанию, организации переездов между населенными пунктами региона оплачивались принимающей стороной [Интервью 2].

Говоря о последствиях заграничной поездки, мужчина, выезжавший в Чехословакию будучи студентом, отметил, что по прибытии в Прагу его удивило наличие платных чистых туалетов. До отбытия поезда в Западночешскую область из столицы Чехословакии в свободное время студенты отправились на прогулку. В эпоху дефицита на Родине, увиденные в Праге в начале поездки 15 различных сортов колбасы в витрине магазина произвели на юношу незабываемое впечатление [Интервью 3]. Распространенной практикой была перепродажа советской водки за рубежом. Однако, как отметил мужчина, побывавший в ФРГ в 1976-1977 гг. и студент, съездивший в Чехословакию в 1989 г., при посещении винного магазина они испытали разочарование: водка продавалась в открытом доступе по той же стоимости, что и в СССР. Количество наименований водки в европейских магазинах исчислялось десятками, а вин - сотнями. Работая в стройотряде на пивоваренном заводе в Пльзене, информант обратил внимание, как отличалась культура тру- 
да: чехословацкие грузчики работали без спешки, равномерно в течение всей восьмичасовой смены, было предусмотрено два технических 15-минутных перерыва и 30-минутный перерыв на обед. Поражало то, что обед выдавали упакованным в одноразовую посуду, в магазинах можно было приобрести готовую продукцию (салаты, горячее и пр.). Когда в один из выходных была организована прогулка в лес между населенными пунктами, лес выглядел очень ухоженным. Во время отъезда домой неожиданностью стало то, что в Праге на вокзале (в отличие от СССР) ночью работал буфет, где продавались напитки и закуски. Мужчина, поделившийся своими наблюдениями, отметил, что поездка, безусловно, способствовала формированию нового восприятия своей страны на фоне окружающего мира [Интервью 3].

Участник анкетирования, проходивший срочную службу в ГДР в 19861988 гг., указал, что Германия показалась очень чистой и аккуратной, возникало ощущение, что «мы так жить не будем никогда!!!». Супруга военного, проживавшая в 1987-1992 гг. в Потсдаме в ГДР, сообщила, что поездка способствовала расширению кругозора, «сломала ряд стереотипов по отношению к иностранцам и к себе». Мужчина-военнослужащий в Лейпциге в ГДР «посмотрел, как живут в соцстранах и определился к чему нам нужно стремиться» [Результаты опроса]. Женщина, работавшая в ГДР бухгалтером в воинской части, указала, что не было желания возвращаться домой. А вот семья мужчины, работавшего во Вьетнаме вернулась домой на год раньше, чем он сам. Разрушенные после войны города, иной климат, связанные с этим санитарные условия, оставлявшие желать лучшего, а также ряд других бытовых факторов не способствовали появлению позитивных впечатлений. Участник поездки в Бельгию сообщил, что встретил «чуждый и не понимающий нас мир».

Анализ различных групп источников позволяет утверждать, что изменения, а порой и кардинальные сдвиги в восприятии мира, несомненно, происходили. Знакомство с повседневной жизнью других стран могло менять отношение человека к себе, к СССР, к стране пребывания или к другим государствам. Оценки в восприятии могли корректироваться незначительно или существенно как в сторону одобрения, так и неприятия. Многое зависело от впечатлений и тех эмоций, которые испытывал человек. Пожалуй, можно даже говорить о существовании феномена выезжающего за границу и эффекте зарубежья.

\section{Библиография}

Акифьева Н.В. Вехи столетнего пути. Очерки истории завода «Русский хром 1915». Екатеринбург: Уральский рабочий, 2015. 174 с.

Бычков А. Под знойным небом Африки // Под знаменем Ленина. 1966. 22 июня. № 122. С. 3. 208 
Виталию Яковлевичу Ариону 75 лет // Иммунопатология, Аллергология, Инфектология. 2008. № 4. С. 6-7.

Гайда Анатолий Войцехович. Биобиблиография ученого (К 60-летию со дня рождения). Екатеринбург: Уро РАН, 2007. 133 с.

Иванова А.С. Магазины «Березка». Парадоксы потребления в позднем СССР. Москва: НЛО, 2017. 297 с.

Интервью 1: мужчина и женщина, поездка во Вьетнам, 1982-84 г. // Архив автора.

Интервью 2: мужчина, поездка в ЧССР, 1969 г. // Архив автора.

Интервью 3: мужчина, поездка в ЧССР, 1989 г. // Архив автора.

Интервью 4: мужчина, поездка в ФРГ, 1976-77 гг. // Архив автора.

Материалы о Костомарове М.И. // Фонд музея Дворца культуры «Огнеупорщик» ОАО «Первоуральского динасового завода».

Нагорных О.С. Особенности сотрудничества советских и китайских врачей в 1950-е гг. (на примере командировки профессора Горьковского мединститута В.Г. Вогралика в Пекин) // Вопросы архивоведения и источниковедения в высшей школе: сборник статей участников XVI Региональной научно-практической конференции (13 декабря 2018 г.). Вып. XV. Арзамас: Арзамасский филиал ННГУ, 2019. С. 255-260.

Новиков Л.Н. Физтех - моя судьба и жизнь // Стенная газета Физико-технического факультета УПИ им С.М. Кирова - УГТУ им Б.Н. Ельцина «ФизикоТехник» [Электронный ресурс] URL: http://new.fizikotekhnik.ru/FizikoTekhnik_Narod/FizikoTekhnik_MemNln.htm (дата обращения: 06.02.2020).

О’Махоуни М. Спорт в СССР. Физическая культура - визуальная культура. Москва: НЛО, 2010. 293 с.

Персидский И. Фильм «Вьетнамские встречи» (1976) // Видеохостинг YouTube [Электронный pecypc] URL: https://www.youtube.com/watch?v=ywUhM_C2-Bw (дата обращения: 09.12.2020).

Персидский И. Фильм «Мы - побратимы» (1981) // Киноархив net-film [Электронный реcypc] URL: https://www.net-film.ru/film-40233/?search=q\%D0\%9F\%D0\%BE\%D0\%B1\%D1\%80\% D0\%B0\%D1\%82\%D0\%B8\%D0\%BC\%D1\%8B (дата обращения: 09.12.2020).

Персидский И. Фильм «Республика Сейшельские Острова» (1981) // Киноархив net-film [Электронный pecypc]. URL: https://dla.net-film.ru/web-tc-mp4/fs43477.mp4 (дата обращения: 09.12.2020).

Пивоваров Н. Кого приглашали в СССР и кого отправляли за границу по религиозной линии (1943-1985 гг.) // Государство, религия, церковь в России и за рубежом. 2017. № 1. C. $185-215$.

Результаты опроса «Зарубежные поездки свердловчан в 1960-80-е гг. как фактор изменения восприятия мира» // Архив автора.

Самокиш А.В. Ю.И. Полянский и его связи с французскими зоологами // Историкобиологические исследования. 2019. Т. 11. № 4. С. 46-61.

Шабалина О.В. Документы фонда № 1 научного архива КНЦ РАН как источники по истории международного научного сотрудничества // Труды Кольского научного центра РАН. 2012. T. 3. № 1. C. 101-110.

Галактионов В. Гость из Африки // Под знаменем Ленина. 1963. 1 нояб. № 217. С. 4.

Крепкие руки дружбы // Каменский рабочий. 1966. 10 сент. № 179. С. 2.

Республика Чад и остров Белый // Уральский рабочий. 1967. 18 апр. № 91. С. 4.

Яковлев В. Вернулся из Индии // Каменский рабочий. 1966. 17 мая. № 96. С. 4.

Альбом друзей // Каменский рабочий. 1966. 3 июля. № 130. С. 1.

Почти год трудился... // Каменский рабочий. 1966. 6 авг. № 154. С. 1.

Друзья обмениваются опытом // Уральский рабочий. 1960. 23 авг. № 199. С. 4. 


\section{ФЕНОМЕНОЛОГИЯ СОВЕТСКОГО ОБЩЕСТВА}

В Болгарию, Японию, Швецию...// Уральский рабочий. 1961. 24 окт. № 251. С. 4.

Вечер дружбы // Уральский рабочий. 1958. 26 окт. № 252. С. 4.

От чешских друзей // Уральский рабочий. 1961. 24 дек. № 299. С. 4.

Coeuré S. Les voyages entre l'URSS et l'Occident: quelle histoire transnationale? // Les Cahiers Sirice 2016/2 (N 16). P. 119-126. (In French.)

Dufraisse S. Démontrer la puissance et parfaire les esprits. Pratiques et objectifs des délégations sportives soviétiques à l'étranger, 1952 - fin des années 1960 // Les Cahiers Sirice. 2016/2 (N 16). P. 35-45. (In French.)

Dufraisse S., Momzikoff S, Pedemonte R. Les Soviétiques hors d'URSS: quels voyages pour quelles expériences? // Les Cahiers Sirice. 2016/2 (N 16). P. 11-18. (In French.)

Dullin S. Des frontières s'ouvrent et se ferment. La mise en place d'un espace socialiste derrière le rideau de fer, 1953-1970 // Presses Universitaires de France «Relations internationales» 2011/3 N 147. P. 35-48. (In French.)

Ermolaeva D. Les délégations soviétiques à l'étranger (de 1953 à la fin des années 1960): Enjeux sociopolitiques et effets du voyage // Carnet du Centre de Recherches en Histoire des Slaves (Université de Paris 1 Panthéon Sorbonne) [En ligne] // CRHS: Centre de Recherche en Histoire des Staves. URL: https://crhs.hypotheses.org/143 (дата обращения 21.01.2021). (In French.)

Gonçalves S. Les danseurs soviétiques à Paris et à Londres pendant la guerre froide: entre travail, tourisme et propagande politique, 1954-1968 // Les Cahiers Sirice 2016/2 (N 16), p. 69-82. (In French.)

Le Poittevin C. L'association «France-URSS» à Toulouse // Slavica occitania Toulouse. 1998. N 7. P. 149-151. (In French.)

\section{References}

Akifyeva N.V. Vekhi stoletnego puti. Ocherki istorii zavoda «Russkij khrom 1915» [Milestones of the centenary path. Essays on the history of the plant «Russian chrome 1915»]. Ekaterinburg: Ural'skij rabochij, 2015. 174 p. (In Russ.)

Al'bom druzej [Friends album]. Kamenskij rabochij [Kamensky worker] 1966. 03.07. N 130. P. 1. (In Russ.)

Bychkov A. Pod znojnym nebom Afriki [Under the sultry skies of Africa]. Pod znamenem Lenina [Under the ensign of Lenin] 1966. 22.06. N 122. P. 3. (In Russ.)

Coeuré S. Les voyages entre l'URSS et l'Occident: quelle histoire transnationale? Les Cahiers Sirice 2016/2 (N 16). P. 119-126. (In French.)

Druz'ya obmenivayutsya opytom [Friends exchange experiences] Ural'skij rabochij [Ural worker] 1960.23.08. N 199. P. 4. (In Russ.)

Dufraisse S. Démontrer la puissance et parfaire les esprits. Pratiques et objectifs des délégations sportives soviétiques à l'étranger, 1952 - fin des années 1960. Les Cahiers Sirice 2016/2 (N 16). P. 35-45. (In French.)

Dufraisse S., Momzikoff S. et Pedemonte R. Les Soviétiques hors d'URSS: quels voyages pour quelles expériences? Les Cahiers Sirice 2016/2 (N 16). P. 11-18. (In French.)

Dullin S. Des frontières s'ouvrent et se ferment. La mise en place d'un espace socialiste derrière le rideau de fer, 1953-1970. Presses Universitaires de France «Relations internationales» 2011/3 N 147. P. 35-48. (In French.)

Ermolaeva D. Les délégations soviétiques à l'étranger (de 1953 à la fin des années 1960): Enjeux sociopolitiques et effets du voyage. Carnet du Centre de Recherches en Histoire des Slaves (Université de Paris 1 Panthéon Sorbonne) [En ligne] URL: https://crhs.hypotheses.org/143 (In French.) 
Fil'm «My - pobratimy» [Film «We are twinned»] (1981). Kinoarhiv net-film [Electronic resource] URL: https://www.net-film.ru/film-40233/?search=q\%D0\%9F\%D0\%BE\%D0\%B1\%D1\% $80 \% \mathrm{D} 0 \% \mathrm{~B} 0 \% \mathrm{D} 1 \% 82 \% \mathrm{D} 0 \% \mathrm{~B} 8 \% \mathrm{D} 0 \% \mathrm{BC} \% \mathrm{D} 1 \% 8 \mathrm{~B}$ (date of access: 09.12 .2020 ).

Fil'm «Respublika Sejshel'skie Ostrova» [Film «Republic of Seychelles»] (1981). Kinoarhiv netfilm [Electronic resource] URL: https://dla.net-film.ru/web-tc-mp4/fs43477.mp4 (date of access: 09.12.2020).

Fil'm «V'etnamskie vstrechi» [Film «Vietnamese meetings»] (1976). YouTube video Hosting [Electronic resource] URL: https://www.youtube.com/watch?v=ywUhM_C2-Bw (date of access: 09.12.2020). (In Russ.)

Gajda Anatolij Vojcekhovich. Biobibliografiya uchenogo (k 60-letiyu so dnya rozhdeniya) [Gaida Anatoly Voitsekhovich. Biobibliography of the scientist (to the 60th anniversary of his birth)]. Ekaterinburg: Uro RAN, 2007. 133 p. (In Russ.)

Galaktionov V. Gost' iz Afriki [Guest from Africa]. Pod znamenem Lenina [Under the ensign of Lenin] 1963.01.11. N 217. P. 4. (In Russ.)

Gonçalves S. Les danseurs soviétiques à Paris et à Londres pendant la guerre froide: entre travail, tourisme et propagande politique, 1954-1968. Les Cahiers Sirice 2016/2 (N 16). P. 69-82. (In French.)

Interv'yu 1: muzhchina i zhenshchina, poezdka vo V'etnam, 1982-84 g. [Interview 1: man and woman, Vietnam, 1982-84]. Arhiv avtora [Author's archive]. (In Russ.)

Interv'yu 2: muzhchina, poezdka v ChSSR, $1969 \mathrm{~g}$. [Interview 2: a man, Czechoslovakia, 1969]. Arhiv avtora [Author's archive]. (In Russ.)

Interv'yu 3: muzhchina, poezdka v ChSSR, 1989 g. [Interview 3: man, Czechoslovakia, 1989]. Arhiv avtora [Author's archive]. (In Russ.)

Interv'yu 4: muzhchina, poezdka v FRG, 1976-77 gg. [Interview 4: man, German Federal Republic, 1976-77]. Arhiv avtora [Author's archive]. (In Russ.)

Ivanova A.S. Magaziny «Berezka». Paradoksy potrebleniya v pozdnem SSSR [The Stores «Birch». Paradoxes of consumption in the late USSR]. Moscow: NLO, 2017. 297 p. (In Russ.)

Krepkie ruki druzhby [Strong hands of friendship]. Kamenskij rabochij [Kamensky worker] 10.09.1966. N 179 (9442). P. 2. (In Russ.)

Le Poittevin C. L'association «France-URSS» à Toulouse. Slavica occitania Toulouse. 1998. N 7. P. 149-151. (In French.)

Materialy o Kostomarove M.I. [Materials about Kostomarov M.I.] Fond muzeya Dvorca kul'tury «Ogneuporshchik» OAO «Pervoural'skogo dinasovogo zavoda» [The Museum fund of the Palace of culture «Refractory» JSC «Pervouralsky refractory plant»]. (In Russ.)

Nagornykh O.S. Osobennosti sotrudnichestva sovetskih i kitajskih vrachej v 1950-e gg. (na primere komandirovki professora Gor'kovskogo medinstituta V.G. Vogralika v Pekin) [The features of cooperation between the soviet and chinese physicians in the 1950s (on the example of trip of Gorky medical Institute' Professor V.G. Vogralik to Beijing)]. Voprosy arhivovedeniya i istochnikovedeniya v vysshej shkole: sbornik statej uchastnikov XVI Regional'noj nauchno-prakticheskoj konferencii (13 dekabrya 2018 g.) [Questions of archivology and source studies in higher education: collection of articles by participants of the XVI Regional scientific and practical conference (December 13, 2018)]. Iss. XV. Arzamas: Arzamasskij filial NNGU, 2019. P. 255-260. (In Russ.)

Novikov L.N. Fiztekh - moya sud'ba i zhizn' [Fizteh - my fate and life] Stennaya gazeta Fizikotekhnicheskogo fakul'teta UPI im S.M. Kirova - UGTU im B.N. El'cina «FizikoTekhnik» [Wall newspaper of the faculty of Physics and technology of the Kirov UPI-USTU named after B.N. Yeltsin «Fizikotekhnik»]. [Electronic resource] URL: http://new.fizikotekhnik.ru/FizikoTekhnik_ Narod/FizikoTekhnik_MemNln.htm (date of access: 06.02.2020). (In Russ.)

O'Mahony M. Sport in the USSR: Physical Culture - Visual Culture. London: Reaktion Books, 2010. 221 p. (In English) 


\section{ФЕНОМЕНОЛОГИЯ СОВЕТСКОГО ОБЩЕСТВА}

Ot cheshskih druzej [From Czech friends]. Ural'skij rabochij [Ural worker]. 1961.24.12. N 299. P. 4. (In Russ.)

Pivovarov N. Kogo priglashali v SSSR i kogo otpravlyali za granicu po religioznoj linii (19431985 gg.) [What Kind of Religious Persons Were Invited to the USSR, and Who Was Allowed to Go Abroad (1943-1985)]. Gosudarstvo, religiya, cerkov' v Rossii i za rubezhom [State, religion, and Church in Russia and abroad]. 2017. N 1. P. 185-215. DOI: https://doi.org/10.22394/2073-72032017-35-1-185-215. (In Russ.)

Pochti god trudilsya... [Almost a year worked...]. Kamenskij rabochij [Kamensky worker]. 1966.06.08. N 154. P. 1. (In Russ.)

Respublika Chad i ostrov Belyj [Republic of Chad and Bely island]. Ural'skij rabochij [Ural worker]. 1967.18.04. N 91. P. 4. (In Russ.)

Rezul taty` oprosa «Zarubezhny`e poezdki sverdlovchan v 1960-80-e gg. kak faktor izmeneniya vospriyatiya mira» [The results of the survey «Foreign trips of Sverdlovsk residents in the 1960s-80s as a factor of changing the perception of the world»]. Arhiv avtora [Author's archive]. (In Russ.)

Samokish A.V. Yu.I. Polyanskij i ego svyazi s francuzskimi zoologami [Yu.I. Polyansky and his connections with French zoologists]. Istoriko-biologicheskie issledovaniya [Historical and biological research]. 2019. T. 11. N 4. P. 46-61. (In Russ.)

Shabalina O.V. Dokumenty fonda N 1 nauchnogo arhiva KNC RAN kak istochniki po istorii mezhdunarodnogo nauchnogo sotrudnichestva [Documents of the fund $\mathrm{N} 1$ of the scientific archive of the kola science centre RAS as the historical sources of international scientific cooperation]. Trudy Kol'skogo nauchnogo centra RAN [Proceedings of the Kola scientific center of the Russian Academy of Sciences]. 2012. T. 3. N 1. S. 101-110.

V Bolgariyu, Yaponiyu, Shveciyu... [To Bulgaria, Japan, Sweden...]. Ural'skij rabochij [Ural worker] 24.10.1961. N 251 (13.995). P. 4. (In Russ.)

Vecher druzhby [Evening of friendship]. Ural'skij rabochij [Ural worker] 1958.26.10. N 252. P. 4. (In Russ.)

Vitaliyu Yakovlevichu Arionu 75 let [Vitaly Yakovlevich Arion 75 years old]. Immunopatologiya, Allergologiya, Infektologiya [Immunopathology, Allergology, Infectology]. 2008. N 4. P. 6-7. (In Russ.)

Yakovlev V. Vernulsya iz Indii [Returned from India]. Kamenskij rabochij [Kamensky worker] 17.05.1966. N 96 (9351). P. 4. (In Russ.) 


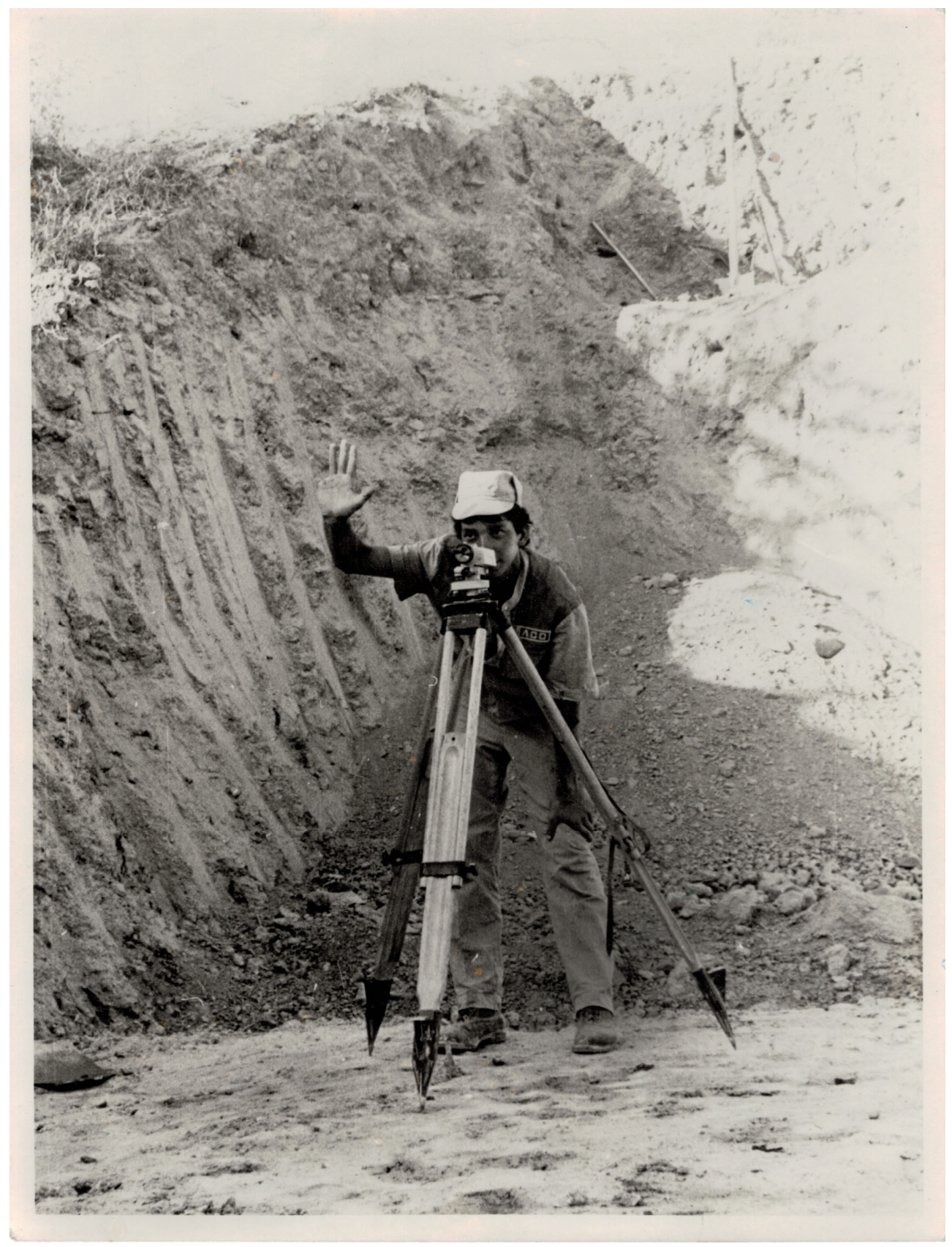

Фото 1. Афганистан. ИнтеротряА

Фото из фондов Музейно-выставочного комплекса УрФУ 


\section{ФЕНОМЕНОЛОГИЯ СОВЕТСКОГО ОБЩЕСТВА}

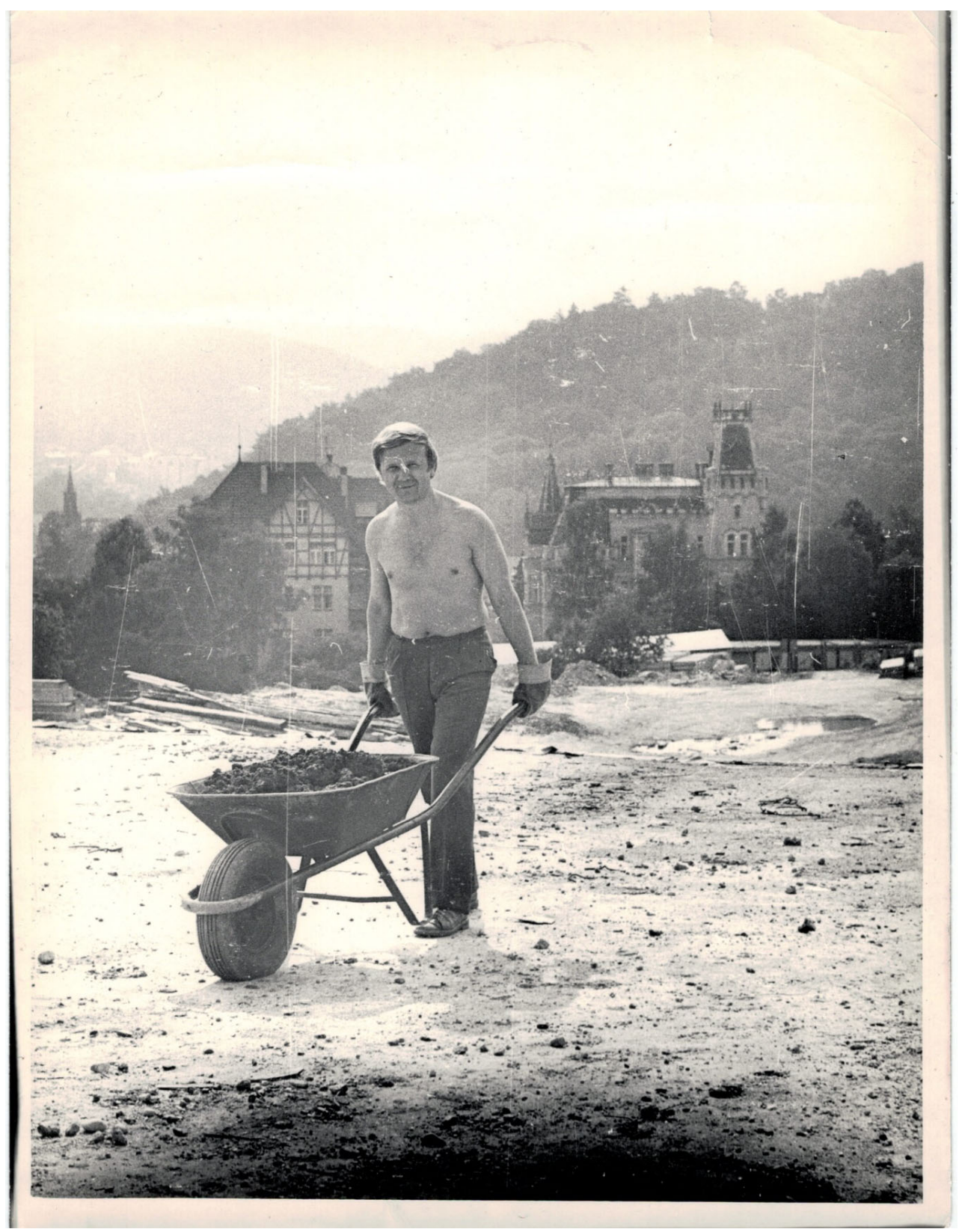

Фото 2. Западночешская область. Интеротряд 1977 г.

Фото из фондов Музейно-выставочного комплекса УрФУ 


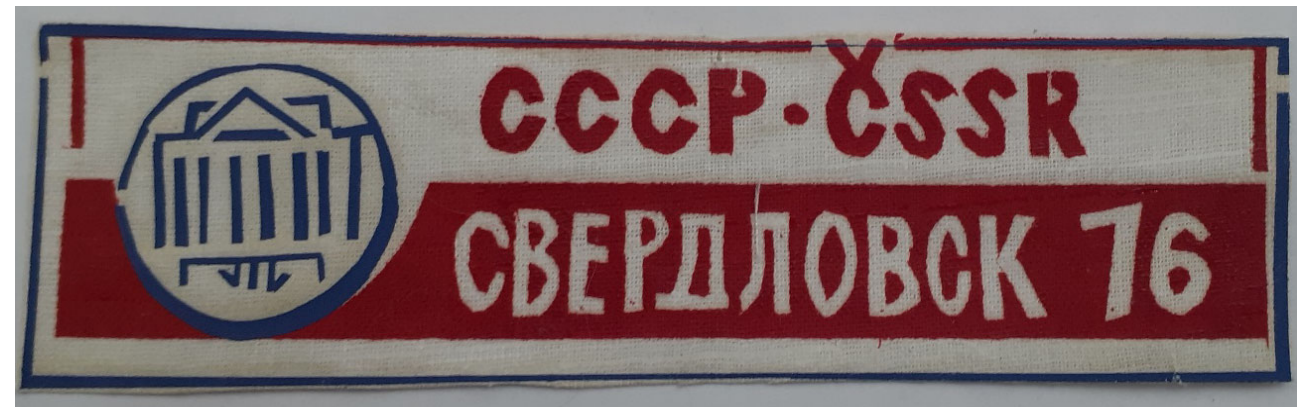

Фото 3. Нашивка на целинку (форменную куртку) интеротряаа из фондов Музейно-выставочного комплекса Урфу

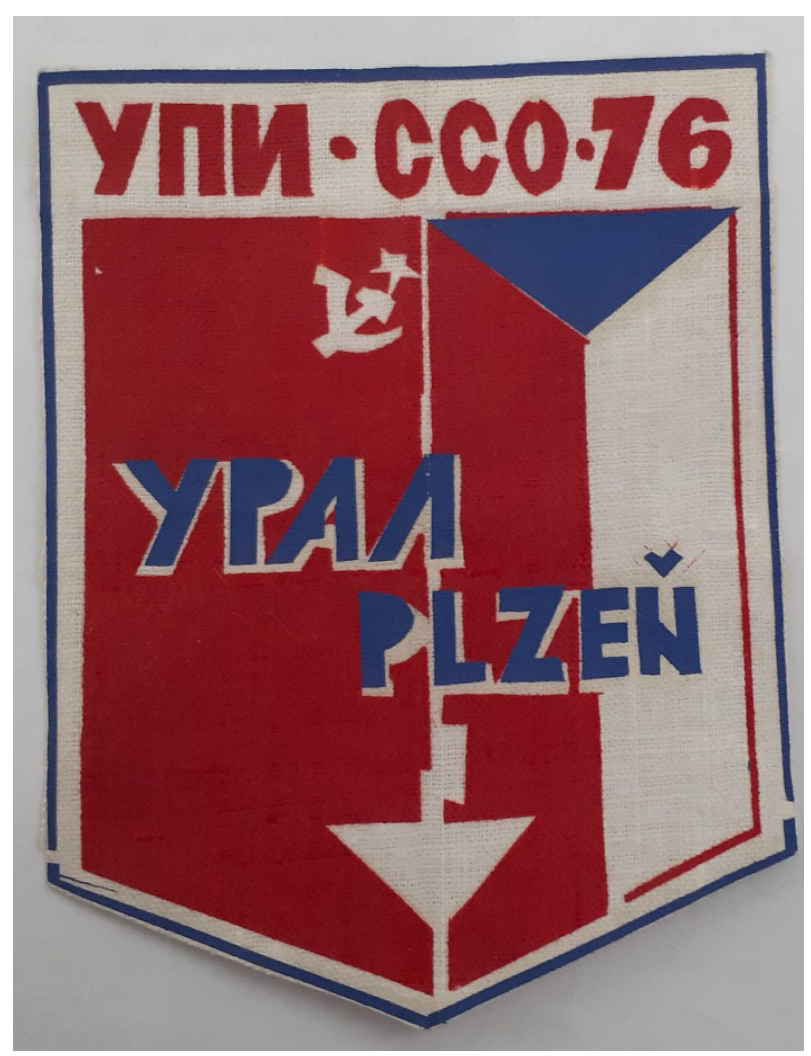

Фото 4. Нашивка на целинку (форменную куртку) интеротряда из фондов Музейно-выставочного комплекса Урфу 